\title{
Widodo's Employment Creation Law, 2020: What Its Journey Tells Us about Indonesian Politics
}

By Max Lane

\section{EXECUTIVE SUMMARY}

- During 2020, the Widodo government introduced a new Bill for parliamentary consideration. This was the Employment Creation Law. It was also known as the Omnibus Law as it introduced amendments to seventy-four other existing laws on a wide range of matters.

- The Bill provoked considerable controversy, especially provisions reducing protection of labour rights and weakening environmental protection laws. Several provisions introducing further deregulation of a range of activities also attracted criticism. The labour and environmental issues were the basis for a series of street protest mobilizations during the year. These also involved mobilizations where university students participated.

- The Law was justified by the government in its supplementary material to the legislation as a strategy to attain a specific growth rate in the gross domestic product and arguing that the revisions in the Law were necessary to substantially improve what was described as Ease of Doing Business.

- Despite the protests and criticism, the law was passed by a big majority in Parliament on 5 October 2020. All member parties of the governing coalition voted for the Bill, and it was signed into law by President Joko Widodo on 2 November 2020.

- The political journey of this Bill into Law revealed very clearly the homogeneity of the Indonesian political elite, represented by the parliamentary parties, all of whom either supported or acquiesced 
to the Law. It was also revealed that sustained and mobilized opposition to the Law was basically confined to a section of civil society, with some sections, including important large trade unions, campaigning in only a moderate and constrained way. 


\section{Widodo's Employment Creation Law, 2020: What Its Journey Tells Us about Indonesian Politics}

By Max Lane ${ }^{1}$

\section{INTRODUCTION}

On 12 February 2020, the Indonesian government sent a draft for a Bill, the Cipta Kerja Bill, to the Indonesian parliament. Soon afterwards the RUU Cipta Kerja Working Committee (Panitia Kerja, or PANJA) was established with representatives from all parties sitting in the committee, except the Justice and Prosperity Party (PKS). The PANJA Committee was headed by a member of Gerindra Party, with a deputy chairperson from the Indonesian Democratic Party of Struggle (PDI-P). ${ }^{2}$ This committee would prepare material for the various stages of the House of Representatives consideration of the Bill. The PDI-P deputy chairperson was Rieke Diah Pitaloka. At the time of the formation of the committee, Pitaloka expressed the sentiment that the government should withdraw the Bill for the time being, and that, in any case, there were opportunities to amend it. She urged that all clauses relating to Labour Law be removed and that the Bill be renamed the Ease of Investment and Permits Bill (Kemudahan Investasi dan Perizinan). Pitaloka had associated herself

\footnotetext{
${ }^{1}$ Max Lane is a Visiting Fellow with the Indonesia Studies Programme at the ISEAS - Yusof Ishak Institute, Singapore. He has written hundreds of articles for magazines and newspapers and several books on Indonesian politics and history. ${ }^{2}$ The PDI-P deputy chairperson was Rieke Diah Pitaloka, formerly outspoken in defence of union rights. For the full list of members, see https://nasional.kompas. com/read/2020/04/20/16035001/tanpa-fraksi-pks-ini-nama-anggota-panjaomnibus-law-ruu-cipta-kerja
} 
with trade union campaigns for reforms over the previous ten years. The government did not act on Pitaloka's suggestions.

Eight months later, the Bill was passed by an overwhelming majority of parliament on 5 October 2020. All member parties of the governing coalition voted for the Bill. Two political parties outside the governing coalition voted against it, although they had not actively campaigned against it during the previous seven months. These were the Demokrat Party, which had been a member of the PANJA, and the PKS. The Bill was signed into law by President Joko Widodo on 2 November $2020{ }^{3}$

During the intervening seven months, which coincided with the growth of the COVID-19 pandemic, the Bill was strongly supported by employer and business groups and opposed by labour, civil society and environmental groups. The bigger trade unions criticized the Bill and lobbied the government to drop the Bill; and there were some street protest campaigns, with the smaller trade unions playing a leading role. Major educational institutions, particularly those connected to private religious schools, opposed specific aspects of the Bill dealing with education. During the deliberation of the Bill, only two amendments of substance were made, removing the provisions relating to the education and media sectors.

\section{THE CONTENTS OF THE LAW}

The RUU Cipta Kerja is a massive document, over 1,000 pages long. ${ }^{4}$ It includes revisions to 73 existing laws, and consists of 15 chapters and 174 articles. The revisions are grouped into 11 different clusters. These are: upgrading of the investment ecosystem, business licensing,

\footnotetext{
${ }^{3}$ https://peraturan.bpk.go.id/Home/Details/149750/uu-no-11-tahun-2020; https://www.kompas.com/tren/read/2020/11/03/114850065/uu-cipta-kerjaresmi-berlaku-ini-sejumlah-pasal-yang-disoroti-pekerja?page=all

${ }^{4}$ For full text of the law, see https://uu-ciptakerja.go.id/salinan-uu-nomor-11tahun-2020-tentang-cipta-kerja/
} 
labour, support for micro, small and medium business, ease of doing business, research and innovation, land acquisition, economic districting, government investment and application of penalties. Its size and breadth led to it also being described as an Omnibus Law-all issues apart from tax, except tax reform, were placed in the one piece of legislation.

Although the Law is named the Employment Creation Law, the Naskah Akademis (Academic Explanation) tabled by the government alongside the Bill makes it clear that direct employment creation is not its immediate framing goal. Employment creation is depicted as an ultimate long-term result of achieving gross domestic product (GDP) growth targets over an extended period. The official rationale of the Law, in line with the Widodo government's general philosophy, is to help Indonesia achieve "an average economic growth of 5.7 (five point seven) percent and real GDP growth per capita of 5 (five) percent" so that "in 2045 Indonesia is predicted to become a developed country with a sustainable economy, the poverty rate close to 0 (zero) percent, and it will have a qualified workforce." ${ }^{\circ}$ The document goes on to affirm that at current growth rates, Indonesia will not reach this goal and will only do so at the earliest in 2059.

The document attempts to explain at considerable length the reasons for the slower than targeted growth. It notes three problems: weak competitiveness, slow growth, and uneven growth between regions. It lists weak competiveness first indicating it sees this as the origins of the overall problem. In assessing this weak competiveness aspect, it states that uses the Ease of Doing Business (EoDB) indicator. It is clear, as will be further discussed below, that the underpinning philosophy of the Widodo government is the single-minded focus of making it easier for the private sector-foreign and domestic - to do business as the way to achieve growth. In this sense, the Widodo government is markedly

\footnotetext{
${ }^{5}$ Kementerian Koordinator Bidang Perekonomian, Naskah Akademis RUU Cipta Kerja, p. 1, https://uu-ciptakerja.go.id/naskah-akademis-ruu-tentang-cipta-kerja/
} 
different from both the Soeharto New Order era government and earlier post-New Order governments insofar as it has dropped all rhetoric around "development", let alone the New Order's "development of the human in his wholeness". Its outlook is that of targeting GDP growth per se not as part of any more rounded development strategy.

In so far as the stated aim of the legislation is to achieve a very big improvement in all aspects of EoDB, it is useful to check how private consultancy firms described the Bill/Law to their client public. Typical of most depictions of it is the one below from the international law firm Baker McKenzie: $^{6}$

- focuses on: (a) increasing the ease of doing business in Indonesia (e.g., simplifying licensing processes, simplifying land acquisition processes, introducing specific provisions on economic zones, creating a land bank supervisory authority, and removing several local filings and registrations such as disturbance permits (izin gangguan) and company registrations (wajib daftar perusahaan); and (b) centralizing the government's investment activity (e.g., creating a government investment authority and fund);

- introduces key amendments to several sectors, notably trade, mining, forestry, mining, plantation, construction, education, transportation (including sea transportation), postal services and broadcasting services;

- introduces several key amendments to the Labour Law, particularly on expatriate licensing requirements, employment termination, contractbased employment, post-termination benefit schemes, employees' rights when there is an acquisition, and severance pay/termination pay;

- reiterates that the Capital Investment Law and investment list will be the main reference for all capital investment activities in Indonesia; and

\footnotetext{
${ }^{6}$ https://www.bakermckenzie.com/en/insight/publications/2020/02/governmentdelivers-long-awaited-draft-omnibus-law
} 
- provides umbrella provisions for the central government to grant tax and fiscal incentives to specific sectors, particularly the tourism sector.

Most law and business consultancies viewed the Law as being aimed at indeed improving the Ease of Doing Business. The summary provided by Baker McKenzie is also a useful summary of the essence of the Law. Below is a summary of some of the key provisions. ${ }^{7}$

\section{More Power to National Government ${ }^{8}$}

The Law allows the government to change existing laws simply by regulation if it deems such changes will encourage faster job creation. It also allows for the creation of an Investment Management Agency that enhances the national government's capacity to initiate as well as strengthen major projects anywhere in the country. This means that a district's economic life could be dramatically changed by a decision by the national government alone. Additionally, governments at the lower levels will need to provide streamlined e-approval systems that are integrated with the national government's system. The national government can now also revoke local regulations that are in contradiction with national regulations.

\footnotetext{
${ }^{7}$ This summary description is taken from a range of existing summaries, after checking against the Legislation. One of the best short summaries, which I have also used in formulating the summary in this article is Esther Samboh, "Guide to Omnibus Bill on Job Creation: 1,028 Pages in 10 Minutes", Jakarta Post, 24 February 2020, https:/www.thejakartapost.com/news/2020/02/21/guide-toomnibus-bill-on-job-creation-1028-pages-in-8-minutes.html

${ }^{8}$ For a comprehensive tabulation of how specific clauses from the numerous amended previous laws compare with the current law, see Schedules 1 and 2 in Oentoeng Suria and Partners, "Indonesia's Omnibus Law: A Breakthrough", https://www.ashurst.com/en/news-and-insights/legal-updates/indonesiasomnibus-law---a-breakthrough/
} 


\section{Labour Issues}

As the Baker McKenzie overview emphasized, severance pay, beyond a basic allowance, is to be reduced or even eliminated. Employers will calculate severance payments according to the employees' length of service only. One area that impacts widely on the factory workforce relates to outsourcing, i.e. the use of labour hire. Outsourcing regulations have been weakened in major ways. Article 66 of the existing Manpower Law prohibits the use of labour hire for workers carrying out core production tasks. This will now be possible. Another change is that enterprises designated labour-intensive will not be subject to regional minimum wages. Province Governors will be able to devise their own calculations for these enterprises or sectors. Micro and small businesses are also exempted from minimum wage settings but wages must be above the poverty line rate. Employees' rights to appeal dismissals have also been eliminated.

To soften these erosions of rights, a new provision is included that allows for payments to laid-off workers, provided both employer and employee have been paying appropriate social insurance premiums. The Law loosens restrictions on the employment of foreign citizens.

\section{Environment}

Law 32/2009 on environmental protection and management set out the processes that companies must implement when carrying out an environmental impact assessment (Analisis Manajemen Dampak Lingkungan, or AMDAL). Such an assessment was required whenever there were to be impacts on the natural landscape, resource exploitation, pollution, socio-cultural situation, heritage and conservation, security, horticulture and animals. ${ }^{9}$ The new Law amends the original Bill so that only activity that has "important effects" of matters defined more

\footnotetext{
${ }_{9}^{9} \mathrm{https} / / /$ www.greenpeace.org/southeastasia/press/43752/warning-omnibus-lawis-threatening-indonesias-sustainable-investment/
} 
generally as "the environment, society, economy and culture" will require an AMDAL. This provision will no longer be regulated by legislation but is to be set out later in a Government Regulation (PP).

An additional amendment has been the removal of the right of appeal against an AMDAL by local residents who claim to be suffering any impact from projects. Committees established to overview AMDALs, made up of representatives from the environment agency, various specialist institutions, qualified experts, environmental organizations and community representatives, are also abolished under the new law.

\section{Building and Safety Regulations Removed}

The new law removes more than twenty clauses, near half of existing clauses, of Law 28/2002 on buildings. Building Permits (IMB), building ownership status and licences for land rights, to licences for architecture and purpose of buildings, among many others, stipulated in previous laws are being removed. Beyond the basically administrative permits, other provisions are being removed that relate to safety, structural requirements, protection against fire and lightning strikes, as well as requirements for health, air, lighting, sanitation, building materials, building comfort, evacuation access and accessibility for disabled visitors. The role of the Investment Coordinating Board (BKPM) has been strengthened in order to streamline the issuing of business licences.

Streamlining means "simplifying" regulations across all sectors of business activity, including maritime and fisheries, agriculture, forestry, energy and mineral resources, electricity and industry. Others are trade, standardization including halal certification, infrastructure and public housing, transportation, health, drugs and food, education and culture, tourism, posts, telecommunications and broadcasting. Areas closed to foreign investment have been narrowed down to narcotics, gambling, endangered flora and fauna, coral reefs, chemical weaponry, industrial chemical and ozone-endangering chemical materials. Outside these areas, the government will be able to ban or allow them, free of legislative restrictions. This will now also apply to foreign investment in the media.

It is clear that the "ease of doing business" has been a major criterion for all these and other changes to existing laws. 


\section{THE POLITICS OF "EASE OF BUSINESS": UNIVERSAL SUPPORT FOR GROWTH, NOT DEVELOPMENT}

The Naskah Akademis to the Employment Creation Law, as mentioned above, emphasizes the need to improve the EoB in order for Indonesia to achieve a GDP growth rate which will eventually, by year 2045, eliminate poverty. The rationale provided in this 220 -page document places the achievement of a statistical growth in GDP as the central overdetermining target. It is the achievement of a set percentage target over a period of years which is assumed to guarantee "close to zero" poverty and that a poor "ease of business" for the private sector is the only major obstacle to achieving that. Of course, achieving economic growth (i.e., growth in GDP) is a goal in the economic policy formulation of all governments everywhere but rarely is it postulated in such an abstract and absolute way as in the Widodo government's justification for the Cipta Kerja Law. Certainly, during the whole period of Soeharto's New Order economic growth targets were paramount. However, such growth targets were set in combination with other targets, either in relation to growth in specific outputs such as in rice production or in relation to social outcomes, such as reducing population growth, replication of community health clinics, building of schools and so on. GDP growth, as a way of also encompassing growth of crony conglomerate sector growth, may have been the overdetermining distorting factor, but it was not so starkly formulated as it is now.

In 2016, when reviewing what she called Widodo's "Narrow Agenda" at the start of his rule, Eve Warburton wrote that "a narrow and no-frills version of an old developmental model is taking shape in contemporary Indonesia". ${ }^{10}$ In fact, it is so "narrow and no-frills" it is not really legitimate to be called a developmental model at all. Widodo's economic

${ }^{10}$ Eve Warburton, "Jokowi and the New Developmentalism", Bulletin of Indonesian Economic Studies 52, no. 3 (2016): 306. 
outlook is not developmentalist but rather "growthist" in its narrowest form. The Naskah Akademis does make fleeting reference to the New Order formulation: "Pembangunan nasional dan pembangunan manusia Indonesia seutuhnya berdasarkan Pancasila dan Undang-undang Dasar Negara Republik Indonesia Tahun 1945."11 (National Development and development of the whole Indonesian person based on Pancasila and the 1945 Constitution.) However, within the document, this goal of "development" is reduced to providing employment which is in turn reduced to the achievement of a simple growth target. This is also the case when discussing the question of quality of human resources. The Naskah Akademis states:

untuk menciptakan lapangan pekerjaan yang mampu menyerap tingginya jumlah tenaga kerja sebagai dampak bonus demografi yang diperoleh Indonesia diperlukan upaya yang sesuai dengan karakteristik persoalan yang dihadapi dalam peciptaan lapangan pekerjaan. Upaya yang dilakukan pemerintah untuk menciptakan lapangan pekerjaan tersebut dilakukan melalui upaya meningkatkan investasi dan kemudahan dan perlindungan UMK. ${ }^{12}$

[to create more employment that can absorb the number of workers resulting from the demographic bonus [of a large young population] in Indonesia, what is needed are efforts in accord with the characteristics of the problem faced in creating employment. The efforts being carried out by the government are through increasing investment and the ease of doing business for and protection of middle-sized business.]

The whole of the 1,000-page Employment Creation Law is aimed at attracting investment by improving the EoB. The Naskah Akademis goes

\footnotetext{
${ }^{11}$ Naskah Akademis RUU Cipta Kerja, p. 207.

${ }^{12}$ Ibid., p. 210.
} 
through the eleven areas where the Law amends existing legislation; and in almost all cases, it underlines how the amendments reduce regulation so as to make it easier for businesses to start projects.

The Employment Creation Law does not, of course, constitute the totality of the Indonesian government's activities. The government, like most governments, carry out a range of programmes, including in Indonesia social safety net and social insurance programmes. During the COVID year of 2020, indeed the Budget had to be revised twice to increase expenditure on the social safety net. However, the government relentlessly pushing through the Law, stripping away labour rights, environmental protections and local government powers, in the name of zero poverty in 2045 through a purely statistical growth formula, embodies more than any other policy implementation of Widodo's brutally, narrow growthist approach. Also significant is that this policy has attracted no resistance from any party in the parliament or any other part of the establishment.

Again, in many ways, the idea that achieving GDP growth through government lowering the costs of investment for the private sector is not unique to Indonesia. It is, however, being pursued in a more "pure" form and more open way by the current government. The simple achievement of a growth target is seen as automatically ending poverty. A pointer to the explanation for this extraordinarily narrow growthism can also be found in some of the data referred to in the Naskah Akademis. In a section explaining the sociological justification of the Law, it states:

Data Kementerian Koperasi dan UMKM menunjukkan 62 juta atau 99\% usaha yang di Indonesia adalah UMKM dengan serapan tenaga kerja sebesar 97\%. ... Namun, dengan jumlah unit usaha yang begitu besar, UMKM dinilai belum mampu mendorong tingkat kesejahteraan masyarakat, utamanya masyarakat menengah ke bawah, ke arah yang lebih tinggi

[Data from the Ministry of Cooperatives and Small and Medium Enterprise indicates that 62 million or 99 per cent of all Indonesian enterprises are small to medium firms and that they absorb 97 per cent of all employment. ... Yet, even with such a large number 
of enterprises, the smaller to medium enterprises are not capable of improving the level of welfare of society, in particular of the middle and lower classes.]

Indonesia inherited an economy from the Dutch East Indies characterized by an overwhelming dominance of very small enterprises. ${ }^{13}$ This was a phenomenon much noted at the time both by Indonesians such as Sukarno, and some critical Dutch economists such as Boeke. The Dutch did not invest in industrializing Indonesia. In 1950, when the Dutch left Indonesia, there was virtually no modern industry, and certainly no modern factories. The largest factories were only those that processed sugar cane or tobacco. By that time, 1950, the developed world was deep into widespread industrialization. Even today, as the Naskah Akademis and other writers have noted, ${ }^{14}$ this remains the case.

This situation has both deep economic as well as political consequences. Economically, it means that the Indonesian private sector, defined by the millions of quite small businesses, has never had the capacity to accumulate sufficient capital to modernize their operation, increase the scale of enterprise and thus embark on a process of continual capital accumulation. In other words, there is no capacity to industrialize being generated within the private sector. What large-scale enterprises operate in Indonesia are either foreign-owned, partly or wholly, or have been financed by "rent" and assisted by the state either formally or as a result of cronyism. There is no wonder that the battle cry of Widodo,

13 Sukarno, "Swadeshi dan Aksi Massa di Indonesia", in Dibawah Bendera Revolusi, vol. 1. This article, written in the 1920s, provides considerable detail in its explanation of the inherent inability if Indonesian business to grow in scale. J.H. Boeke, Oriental Economics (New York: International Secretariat, Institute of Pacific Relations, 1947).

${ }^{14}$ Max Lane, Unfinished Nation: Indonesia Before and After Suharto (London: Verso, 2008), see the chapter on "The Political Economy of Aksi". Also Max Lane, Decentralization and Its Discontents: An Essay on Class, Political Agency and National Perspective in Indonesian Politics (Singapore: Institute of Southeast Asian Studies, 2014). 
as President, a person coming out of the district-level middle-enterprise business milieu, is "Investment, Investment, Investment". In a situation of tens of millions of small businesses as the primary component of the private sector competing to deal with a multi-layered and underpaid (and therefore necessarily corrupt) civil service, it is no wonder either that the second battle cry is "Ease of Business, Please!".

While this situation continues, however, direct support from the state, both formally and via crony relationships, continues to be necessary. Under Widodo, state-owned companies have been used to support the infrastructure needed to attract development and deep relationships between elite figures, often from the New Order period, and natural resource ownership and control continue, which is one of the primary bases of Indonesia's small number of big conglomerates. ${ }^{15}$

This situation of the numerical domination of small businesses has also had a fundamental socio-political consequence, which also underpins the almost universal support for the Employment Creation Bill among the broad business and political elite. The inability of the private sector to give birth to a larger number of big enterprises (in relation to the size of the country) in what is essentially a capitalist society means the "national" political elite overwhelmingly comprises hundreds of business-based local political elites. Only a very few families, based in big business, or with historical significance, can be considered as being nationally based rather than locally based. This is also reflected in the party system. While all parties participating in elections (except those from Aceh) must show they have a significant national spread, elections reveal that their voter support tends to be concentrated in specific regions. Ninety per cent of the party elites share a common class background - they are from local business or bureaucratic elite families whose political field of operation and influence is also fundamentally local. ${ }^{16}$ The coalitions of parties

\footnotetext{
${ }^{15}$ For an analysis from an environmentalist perspective listing some ownerships of natural resource companies, see https://news.mongabay.com/2019/10/ indonesia-cabinet-jokowi-widodo-oligarchs-environment/

${ }^{16}$ See Ch. 4, "National Agency in a 'Co-ordinative State': The Future of Decentralization", in Lane, Decentralization and Its Discontents.
} 
formed, such as the current coalition under Widodo, are in many ways (although not in a simple way), coalitions of regional elites.

Another way in which President Widodo's outlook on achieving economic growth can be seen to reflect the combination of a kabupaten capitalist's outlook with that of the national resource conglomerate relates to the emphasis on equalization of the ease of doing business among the regions. Although rarely discussed after 2016, the initial framework of this discussion was around the idea of a "maritime tollway", i.e. of a programme to improve the national transportation infrastructure in a way that would assist regionally based businesses, which would include big resource-based projects in the regions as well as the thousands of kabupaten and provincial level small and medium businesses. In the case of the justifications for the Employment Creation Bill, of the only three key hindrances to achieving the ongoing GDP growth targeted given in the Materi Akademis, the unequal ease of doing business at the local level is the third point. ${ }^{17}$ There is tension between the increasing of power for the national government to intervene in provincial-level business affairs and the loosening of regulations that affect local business whose resolution over the coming period will be interesting to watch.

Politically, this reflects the dominance within the national eliteand thus parliament and government - of the same social layer from which Widodo comes. They all share his battle cry: Investment! Ease of Business! And this battle cry is equally shared by Indonesia's big capital, historically assisted by state and crony support. If Widodo is the representative of the nation's kabupaten capitalists, the Coordinating Minister for Maritime Affairs and Investment, Luhut Binsar Pandjaitan, represents this latter segment. ${ }^{18}$

\footnotetext{
${ }^{17}$ Naskah Akademis RUU Cipta Kerja, p. 207.

${ }^{18}$ Luhut is a major player in coal mining, petroleum, gas and electricity among other businesses. His business ownerships are registered on his ministerial homepage: https://maritim.go.id/portfolio/luhut-binsar-pandjaitan/ as well as being critiqued in https://news.mongabay.com/2019/10/indonesia-cabinetjokowi-widodo-oligarchs-environment/
} 
Indonesian politics, currently, is constituted by the unity of these

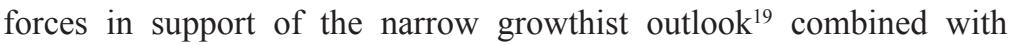
the rivalries and bargaining among the parties, each rooted in some combination of local elites, with the occasional party also headed by a conglomerate-based figure.

It is these political and economic factors that underpin the almostuniversal support within the elite of the Employment Creation Law.

\section{THE EDUCATION AND PRESS PROVISIONS OF THE BILL ARE REMOVED}

The one area where significant clauses were removed from the Bill related to education. The controversy over this issue also originated from the private sector-driven growthist strategy. The Bill, in its original form, required educational institutions to have a business permit (izin usaha), despite the fact that most schools and universities are not owned by private businesses but by various forms of non-profit institutions. In September 2020, a coalition of organizations dealing with education issued a critique of the cluster of clauses dealing with education and called for that section of the Bill to be withdrawn. ${ }^{20}$ The coalition comprised a very representative range of institutions. These included the key education bodies of Muhammidiyah and Nahdlatul Ulama ${ }^{21}$ as well as the national association of private universities and the main teachers union. The secular Taman Siswa educational foundation was also part of the coalition. The coalition honed in on the Bill's implied redefinition of educational activity as a business activity:

\footnotetext{
19 Warburton, "Jokowi and the New Developmentalism", see throughout her article. Warburton's article is one of the first to highlight the narrowness of Widodo's vision.

20 https://nasional.kompas.com/read/2020/09/23/07414381/tolak-klasterpendidikan-masuk-ruu-cipta-kerja-organisasi-pendidikan-beri-12?page=all

${ }^{21}$ Some NU figures were more broadly critical of the law beyond education sector impacts, including its erosion of worker protections. https://www.cnnindonesia. com/nasional/20201007161530-20-555563/said-aqil-ciptaker-untungkankapitalis-tindas-rakyat-kecil
} 
Pengaturan ketentuan Pendidikan dan Kebudayaan dalam RUU Cipta Kerja masuk dalam BAB III tentang Peningkatan Ekosistem Investasi dan Kegiatan Berusaha menandakan secara paradigmatik menempatkan pendidikan dan kebudayaan masuk rezim investasi dan kegiatan berusaha. Hal ini telah menggeser politik hukum pendidikan menjadi rezim perizinan berusaha melalui penggunaan terminologi izin berusaha pada sektor pendidikan, yang sesungguhnya tidak berorientasi laba. ${ }^{22}$

[The regulation of Education and Culture in the Employment Creation Bill in Chapter III about the Improvement of the Business Activity and Investment Ecosystem creates a paradigm where education and culture are classified as under a business and investment regime. This shifts legal policy in relation to education by using the terminology of a business permit for the education sector which in actuality is not oriented to profit.]

The coalition also pointed out that existing laws regarding education and culture affirmed that state policy in this sector had fundamental philosophical orientations that clashed with an approach that saw education as purely another profit-making exercise.

This controversy underlines the narrowness of the government's growthist approach. In the case of education, however, it came up against the opposition of major, large vested interests - the massive non-profit religious and private educational institutions. In response to this and other similar criticisms and opposition, it was announced by the parliamentary body oversighting the processing of the Bill that the cluster of clauses dealing on education would be withdrawn. ${ }^{23}$ It was stated that this had been proposed also by the Ministry of Education and Culture after hearing critiques from the education sector.

\footnotetext{
${ }^{22}$ Ibid.

${ }^{23}$ https://nasional.tempo.co/read/1391124/dpr-pastikan-klaster-pendidikandicabut-dari-ruu-cipta-kerja
} 
However, in October when the Bill was passed, attention was drawn to the fact that clauses about applying for business permits for education remained in the Law. ${ }^{24}$ This drew criticisms again from most of the education sector. Some members of parliament expressed surprise also that there were still provisions regarding education in the Bill. There were also criticisms of this surprise inclusion from members of the parliamentary commission dealing with education. ${ }^{25}$ The provision that appeared in the final Bill, then signed into law by the President, had been pared down to one clause that stated that a business permit "may" be applied for an educational activity. Critics argued that that allowed for a new approach to education, allowing it to become a purely business commodity. The Ministry of Education and Culture, however, denied that this represented an educational cluster in the final law and asserted that all the existing laws would remain unamended, and thus educational activity would still be guided by the philosophical and pedagogical stipulations of those laws. ${ }^{26}$ The clause remains in the Law.

The other cluster that was removed from the Bill related to the press. ${ }^{27}$ All major press institutions, including the Press Council as well as journalist associations, opposed this cluster. There were two major aspects which attracted criticism. One related to the role of foreign capital in investing in the media - the new law basically left it up to the share market, with no apparent limitations. The other related to the provision for huge fines on the media for vaguely formulated wrongdoings related to hindering media operations.

\footnotetext{
${ }^{24}$ https://www.cnnindonesia.com/nasional/20201006204736-20-555186/pasalpendidikan-di-omnibus-law-yang-dinilai-membingungkan

25 https://tirto.id/komisi-X-dpr-kaget-klaster-pendidikan-tetap-masuk-uu-ciptakerja-f5EG

${ }^{26} \mathrm{https}$ //nasional.kompas.com/read/2020/10/19/11210341/kemendikbud-klaimtak-ada-klaster-pendidikan-di-uu-cipta-kerja

27 https://nasional.kontan.co.id/news/dpr-dan-pemerintah-sepakat-keluarkanpasar-pasal-tentang-pers-dari-ruu-cipta-kerja
} 
In both the education and press cases, the initial clusters of provisions further underlined the philosophical outlook that tended to see all activity as essentially business activity that needed support in achieving private sector-driven GDP growth targets.

\section{CAMPAIGNING OPPOSITION TO THE EMPLOYMENT CREATION LAW}

It is often noted that there has been substantial opposition to the Law. The situation is however more complicated. Significantly, the campaign against the Law was not enough to either stop it or even see it amended. It could be fairly stated that in terms of stopping or substantially amending the law, the oppositional campaigns were a total failure. The same can be said of the protests in 2019 against legislation passed that weakened the Corruption Eradication Commission (KPK). An analysis of this opposition can reveal the terrain of Indonesian politics today. If relations among the party-based conglomeration of local elites and with conglomerates frames mainstream politics, it is the steadily increasing pressure to break out of a state of disorganization among youth and nonelite social layers which framed dissident politics.

There were two major oppositional fronts, which sometimes combined for protests. One front was the opposition by environmental groups to the weakening of the need for Environmental Impact Studies. Another was the trade union opposition to the erosion of labour rights. While there were some voices raising concerns about the government's new power to override legislation through government regulation and to weaken regional government powers, this did not become an issue that provoked ongoing oppositional campaign activity.

Both trade unions and environmental organizations issued statements criticizing those parts of the Law that eroded rights in their areas. In terms of the nature of the campaigns against the Law that occurred, developments revealed that it was only those unions and groups that could be classified as part of the social justice wing of civil society that actually mobilized forces on the ground in any ongoing way. These combined with a variety of student elements, although never in large numbers. 
During 2020, there were several protest mobilizations against the Law. These were mostly initiated by coalitions of civil society organizations, with trade unions providing the organized critical mass, except in Yogyakarta where students provided that. It is only trade unions that currently have a sufficient stable organization and geographic spread to carry out planned protests. Environmental groups usually do not have tightly organized large memberships but operate as either organizations based on paid staff or loose networks of locally based activist groups. The only student organizations with a stable mass membership are those affiliated to political parties - and all parties that have sizeable student groups support the Law. Student mobilizations for the protests relied mostly on the smaller progressive organizations and spontaneous participation.

The first protests took place in January 2020 at Parliament House. Newspapers reported that there were thousands present. ${ }^{28}$ The Confederation of Indonesian Trade Unions (KSPI) also mobilized in the protest. Responding to the protest, several members of parliament also expressed their opposition. These included Prosperous Justice Party (PKS) MP Ansory Siregar, Indonesian Democratic Party of Struggle (PDI-P) MP Ribka Ciptaning Proletariyati, National Mandate Party (PAN) MP Saleh Partaonan Daulay and PKS MP Netty Prasetiyani. Gerindra Party MP Obon Tabroni, formerly an official in the KSPI Union Confederation, proposed that the DPR only reject revisions related to labour regulation. The KSPI also instituted legal proceedings against the Bill. ${ }^{29}$ It also threatened a national strike of its members.

Besides KSPI, another component to these mobilizations was GEBRAK (Labour Movement with the People). GEBRAK (which

\footnotetext{
$28 \mathrm{https}$ //www.thejakartapost.com/news/2020/01/21/we-will-continue-toprotest-labor-unions-insist-on-rejecting-omnibus-bill-on-job-creation.html; http://www.asia-pacific-solidarity.net/news/2021-01-18/kspi-urges-mk-courtoverturn-harmful-job-creation-law.html

29 http://www.asia-pacific-solidarity.net/news/2021-01-18/kspi-urges-mk-courtoverturn-harmful-job-creation-law.html
} 
also means "smash through") comprises both trade unions and civil society organizations. While there are several unions that work through GEBRAK, probably the most significant is the Indonesian United Workers Confederation (KPBI), whose president and spokesperson is Ilhamsyah. He was quoted in the press with the following criticisms. ${ }^{30}$ "Under the formulation of setting wages per hour, in essence this is just manipulation so they (employers) can pay lower wages. Because of this, the Omnibus Law is clearly in the interests of employers, in the interests of investment", Ilhamsyah told KBR new agency on Monday, 20 January 2020.

Ilhamsyah believes that the application of the Omnibus Law Cipta Lapangan Kerja (Cilaka) Law will reduce workers' incomes, reduce the public's spending power and increase violations against workers. "Under a working relationship that is flexible, they (employers) can easily recruit workers. But it will also be easy to sack workers later. This is what they're planning, how all types of work will be allowed to be outsourced and use contract labour systems", explained Ilhamsyah. "If currently there are only five types of jobs that can be outsourced, under the Draft Omnibus Law, all types of jobs will be allowed to be outsourced. This means, contract labour can be used in all types of jobs", he continued.

There was an even broader coalition formed to respond to the proposed law, called the Fraksi Rakyat Indonesia (FRI), comprising forty civil society organizations, including nine trade union federations or confederations..$^{31}$ These were the Konfederasi Kongres Aliansi Serikat Buruh Indonesia (KASBI), Konfederasi Persatuan Buruh Indonesia

\footnotetext{
${ }^{30}$ https://kbr.id/nasional/01-2020/gebrak__upah_per_jam_itu_akal_akalan_ pengusaha/102021.html

${ }^{31}$ Kertas Posisi, Fraksi Rakyat Indonesia (FRI), Omnibus Law RUU Cilaka: Aturan Berwatak Kolonial at https://www.walhi.or.id/omnibus-law-ruu-cilakaaturan-berwatak-kolonial; https://www.hukumonline.com/berita/baca/ 1t5e3474fe03a84/12-alasan-koalisi-masyarakat-sipil-tolak-ruu-cipta-lapangankerja/
} 
(KPBI), Sentra Gerakan Buruh Nasional (SGBN), Konfederasi Serikat Nasional (KSN), Pergerakan Pelaut Indonesia, Jarkom Serikat Pekerja Perbankan, Serikat Pekerja Media dan Industri Kreatif untuk Demokrasi (SINDIKASI) and the Federasi Pekerja Pelabuhan Indonesia. ${ }^{32}$ It was through a coalition such as FRI that environmental organizations, including the largest environmental organization WAHLI, participated in the movement against the Omnibus Law.

By the end of February, ${ }^{33}$ it seemed that there was a potential for a very large movement against the Bill. Apart from GEBRAK and FRI with its core union base, those unions listed above, the three union confederations with the largest formal membership also announced the relaunching of an old coalition, the Indonesian Trade Union Council (MPBI). The three confederations are the Confederation of the All-Indonesian Workers Union (KSPSI), the Confederation of Prosperity Labour Unions (KSBSI) and the Confederation of Indonesian Trade Unions (KSPI). Most trade unions in GEBRAK/FRI did not support any of the 2019 Presidential candidates, whereas these three unions did. The KSPSI and KSBSI gave their support to the presidential ticket of then incumbent President Joko Widodo and vice-presidential candidate Ma'ruf Amin while the KSPI decided to support the rival ticket of Prabowo Subianto and Sandiaga Uno. The MPBI was originally established on 1 May 2012 at a declaration attended by 100,000 workers at the Bung Karno Sports Stadium.

This meant that by March 2020, the two main wings of the union movement - those unions aligned with or which had supported parliamentary parties or Presidential candidates and those refusing to become aligned and opposing the incumbent parties - had formed coalitions and made commitments to campaign against the Bill. All unions, including the large elite-aligned unions, had threatened largescale strike action. It should be noted here that it is the MPBI unions,

\footnotetext{
${ }^{32}$ For some information on the very complicated trade union terrain in Indonesia, see Max Lane, An Introduction to the Politics of the Indonesian Union Movement (Singapore: ISEAS - Yusof Ishak Institute, 2019).

${ }^{33} \mathrm{https}: /$ nasional.kompas.com/read/2020/02/28/22423901/tiga-serikat-buruhsepakat-bersatu-lawan-omnibus-law-ruu-cipta-kerja
} 
especially the KSPSI and KSPI, that appear to have the largest duespaying memberships. The GEBRAK and other non-aligned unions are considerably smaller. The KSPSI and KSPI have inherited some of the workplaces and networks from the union federation that existed during the thirty-two years of the New Order, giving them a huge organizational and political head start comparted to the other unions whose origins was the anti-New Order activism. ${ }^{34}$

During March, there were union protests in a number of cities, including Jakarta. However, on 18 March, the MPBI unions announced that because of the risk of spreading COVID-19, they would postpone the huge mobilizations they had promised and concentrate instead on conducting a "political safari". ${ }^{35}$ The KPBI, the core confederation in GEBRAK, also postponed demonstrations due to the COVID-19 issue. ${ }^{36}$ During April there was also a WhatsApp message campaign targeting MPs by most of the unions. ${ }^{37}$ The MPBI's planned May Day rally was also shifted online, and they carried out some charity work in relation to COVID-19.

The MPBI union's demobilization was rewarded with an invitation by President Widodo to meet in the Presidential Palace. There was an announcement also that the parliaments' deliberation of the Bill would be postponed..$^{38}$ However, it later became clear that all that was involved would be a scheduling of hearings so that the labour provisions in the

\footnotetext{
${ }^{34}$ See Lane, An Introduction to the Politics of the Indonesian Union Movement.

35 https://www.liputan6.com/bisnis/read/4205508/ada-virus-corona-buruhtunda-aksi-besar-besaran-tolak-omnibus-law; https://www.thejakartapost. com/news/2020/04/03/labor-union-to-hold-massive-protest-in-jakarta-despitephysical-distancing-measures.html

36 https://www.cnnindonesia.com/nasional/20200407152602-32-491264/buruhdpr-tak-peduli-rakyat-bahas-omnibus-law-saat-corona

37 https://www.thejakartapost.com/news/2020/04/09/workers-blast-lawmakerswith-messages-opposing-omnibus-bill-on-job-creation.html

38 https://www.thejakartapost.com/news/2020/04/24/govt-house-delaydeliberations-over-labor-issues-in-omnibus-bill-amid-backlash.html
} 
Bill would be discussed last. ${ }^{39}$ Even this was strongly opposed by the Indonesian Employers Association (Apindo) who argued that the delay would create uncertainty for investors, especially given the insecurity already created by the impact of COVID- $19 .{ }^{40}$ In reality, there was no effective delay with the 1,000-page Bill being passed into legislation by November.

Between April and October, protest mobilizations were sporadic. The MPBI unions focused on dialogue with the government until it was clear in October when the Bill would pass, that preparations for protest actions and strikes were announced. There were walkouts from tripartite discussions, by representatives of both KPBI and KASBI. By October, even the KSPI was expressing dissatisfaction with the minimal results of the talks. When a new round of mobilizations was launched in October and into November, they took place as a last gasp, after the legislation had been passed with no serious amendments to the labour provisions being achieved - or of any other amendments.

This final wave of mobilizations relied on the GEBRAK unions and civil society groups, and semi-spontaneous student mobilizations to achieve their numbers, which was on average in the thousands down to hundreds. Mobilization by large factories organized by the KSPSI and KPSI were rare, and when they did take place, they did so with minimal back-up from their national structures. ${ }^{41}$ GEBRAK itself is Jakartabased but there were similar coalitions operating in other cities that spearheaded the mobilizations. In almost all cases, these coalitions did not include MPBI unions. The last wave of mobilizations relied primarily on coalitions that represented the social justice wing of civil society, including some unions, and formed a social opposition, opposing policies but not representing forces that could be an alternative government. Their

\footnotetext{
${ }^{39}$ http://www.asia-pacific-solidarity.net/news/2020-04-21/omnibus-bill-jobcreation-labor-articles-be-discussed-last-amid-public-protests.html ${ }^{40} \mathrm{https}$ //www.thejakartapost.com/news/2020/04/28/business-groups-opposeomnibus-bill-delay-as-mass-layoffs-loom.html

${ }^{41}$ Communications with trade union activists in Bekasi Karawang area.
} 
basic demand was for the Law not to be passed or signed into law by the President.

\section{CONCLUSION}

The journey of the Employment Creation Law from presentation to Parliament, to being signed into law reveals some key features of the Indonesian political economy. The support for the legislation among all the Indonesian parliamentary political parties, with only minor tactical resistance from two of them, exposes the fundamental shared base of these parties, with their core support base in specific areas of the country, but among exactly the same social layer, namely overwhelmingly numerically predominant small and medium business, all invested in Widodo's "growthism". This layer operates in tandem with a small number of large conglomerates, now often referred to among their critics as "oligarchs". The formal justifications provided for the Law also confirm even more starkly than previously that the government's economic strategy is based on a single-minded focus on reaching narrow statistical growth targets to be facilitated by improving "ease of business" through deregulation, even if it means the removal of labour, environmental and local government rights.

The fate of criticism of this legislation and the narrow growth-oriented philosophy behind it reveals that only a minority of the union movement was inclined towards industrial or political mobilization to block the withdrawal of rights. The opposition campaign has also revealed that it was the most critically minded university students who are the most likely allies in such campaigns. This combination, at the present time, is not sufficient to block the government's policies, which are universally supported by the current parliamentary parties. This scenario also exposes the reality that neither labour nor social justice civil society yet have their own parliamentary representation.

The withdrawal of parts of the legislation seen to be forcing education into an overly business format reflects the considerable social weight of the major religious organizations that dominate the non-government education sector. The fact that profit-oriented educational businesses are still to be facilitated also points to the limits of their power. 